\title{
IMMUNOHISTOCHEMICAL DISTRIBUTION OF S-100 PROTEIN AND CYTOSKELETAL PROTEINS (A-ACTIN, DESMIN AND VIMENTIN) IN BOVINE TONGUE AND SOFT PALATE
}

Amin Hassanin ${ }^{1}$, Elnasharty Mohamed ${ }^{2}$ and Galal A.E. Youssef ${ }^{3}$

${ }^{1}$ Department of Cytology and Histology, Faculty of Vet. Med., Kafr El-Sheikh University, Kafr El-Sheikh, Egypt.

${ }^{2}$ Department of Cytology and Histology, Faculty of Vet. Med., Alex. University, Damanhur Branch, Al-Bostan, Damanhur, Egypt.

${ }^{3}$ Department of Anatomy and Embryology, Faculty of Vet. Med., Mansoura University, Mansoura, Egypt.

\begin{abstract}
Distribution and localization of $S-100$ protein and cytoskeletal proteins, $\alpha$-actin, desmin and vimentin, in the bovine tongue and soft palate were investigated using immunohistochemistry. S-100 protein was expressed in the taste buds and connective tissue core of circumvallate papillae, moderate immunoreactivity were occur in subepithelial connective tissue cells of the tongue and soft palate. The serous secreting cells and ducts cells in the lingual salivary gland, as well as serous demilunes of mixed palatine salivary glands were strongly immunopositive for $S-100$ protein. Mucous cells the palatine salivary glands were constantly negative for all tested proteins. Positive staining for $\alpha$-actin and desmin were observed in the myoepithelial cells, smooth muscle fibers of blood vessels in addition to intrinsic skeletal muscles of tongue and soft palate. Desmin was
\end{abstract}


expressed in stratum granulosum of keratinized epithelium and supranuclear region of lingual salivary glands. Vimentin was always present in connective tissue cells and nerve bundles in both tongue and soft palate. These results revealed a tissue specific distribution of the tested proteins in bovine tongue and soft palate; that highlight for the use of these proteins as markers for many morphological and pathological aspects.

\section{INTRODUCTION}

S-100 protein is classified into a group of calcium binding proteins (Isobe et al., 1982; Kahn et al, 1991) with a low molecular weight of about 10-24 kDa (Fano et al., 1995) that are important in intracellular calcium metabolism (McNutt, 1998). S-100 protein was thought to regulate diverse groups of cellular functions including cell growth, energy metabolism, contraction and intracellular signal transduction (Zimmer et al., 1995). It was first isolated in the brain and it has long been considered as specific to the nervous system (Bock, 1978). However, subsequent studies revealed presence of S-100 protein in other tissues as human testis (Haimoto et al., 1987), human epidermis (Rowden et al., 1985), bovine testis (Amselgruber et al., 1992; Cruzana et al., 2003) and a wide variety of organs and tissues including lymph nodes, spleen, thymus, pancreas, salivary and mammary glands (Nakajima et al., 1982; Turusov, 1990; Momotani et al., 1993; Nagasao et al., 2002). Antibodies against S-100 are widely used in diagnosis of human tumors (Turusov, 1990) and have been shown to be a useful marker for the epidermal Langerhans cells (Takahashi and 
Nakano, 1989). Cytoskeletal proteins desmin and vimentin are intermediate filaments (about $10 \mathrm{~nm}$ in diameter) and microfilaments $\alpha$ actin (diameter up to $7 \mathrm{~nm}$ ) are normal constituents in the cells but they have a high degree of cell lineage specificity (Weber and Osborn, 1982; Weber and Geisler, 1984). $\alpha$-actin is a contractile protein present in muscle and some non-muscular tissues (Skalli et al., 1986) and detected in myoepithelial cells (Zedda and Farina, 1998). Desmin is normally present in muscular tissues (skeletal, smooth and cardiac muscles) and its expression is highly specific for muscle and their tumors (Azumi et al., 1988). Vimentin is present in most of mesenchymal cells (Azumi and Battifora, 1987), it was localized in epidermal fibroblasts in human skin (Rappersberger et al., 1990) and expressed in smooth muscles of blood vessels (Gabbiani et al., 1981).

Little information about the expression of S-100 protein and cytoskeleton proteins in bovine tissues are available. The present study describes the exact localization and differential distribution of S-100 protein and cytoskeletal proteins ( $\alpha$-actin, desmin and vimentin) in bovine tongue and soft palate.

\section{MATERIALS AND METHODS}

\section{Sampling:}

Specimens from the tongue and soft palate were obtained from 15 healthy adult cattle of both sexes immediately after slaughtering. It washed with phosphate buffer solution (PBS) then fixed in Bouin's solution for 18 hours. 


\section{Preparation of paraffin sections:}

After fixation, specimens were routinely dehydrated in ethanol and embedded in paraffin for sectioning. By using of rotary microtome, 5$7 \mu \mathrm{m}$ thickness sections were obtained and mounted on poly- $L$-lysine coated slides.

\section{Immunohistochemistry:}

Table (1): Antibodies that used in the current study are shown with their dilution.

\begin{tabular}{|c|c|c|c|c|c|}
\hline Antibodies & Name & Type & Code & Source & Dilution \\
\hline \multirow{4}{*}{ Primary } & Rabbit anti S-100 & Polyclonal & Z0311 & Dako & $1: 600$ \\
\hline & Mouse anti $\alpha$-actin & Monoclonal & M0851 & Dako & $1: 200$ \\
\hline & Mouse anti-desmin & Monoclonal & M0760 & Dako & $1: 50$ \\
\hline & Mouse anti-vimentin & Monoclonal & M7020 & Dako & $1: 200$ \\
\hline \multirow{2}{*}{ Secondary } & Biotinylated goat anti-rabbit & Polyclonal & BA-1000 & Vector & $1: 200$ \\
\hline & Biotinylated goat anti-mouse & Polyclonal & BA-9200 & Vector & $1: 200$ \\
\hline
\end{tabular}

\section{Procedure:}

Tissue sections were deparaffinized and rehydrated for immunostaining using the avidin-biotin peroxidase complex (ABC) method (Hsu et al., 1981). Sections were pretreated with $3 \% \mathrm{H}_{2} \mathrm{O}_{2}$ in methanol for 15 minutes to block the endogenous peroxidase activity followed by three times washing with PBS, then incubated with $2 \%$ normal goat serum for 30 minutes to block the unspecific binding sites. The primary antibodies against S-100 protein, $\alpha$-actin, desmin and vimentin were diluted in PBS (Table 1) and applied on tissue sections 
then incubated at $4^{\circ} \mathrm{C}$ in moisture chamber overnight. After three times washing with PBS the biotinylated secondary antibodies were applied (Table 1) for 30 minutes at room temperature followed by three times washing with PBS.

ABC (Avidin Biotin peroxidase Complex, K0355 Dako) was diluted (1ml PBS $+10 \mu \mathrm{l}+10 \mu \mathrm{B})$ then applied on sections for 1 hour at room temperature, then rinsed by PBS. Immunostaining was visualized by 3, 3-diaminobenzidine (DAB) and $\mathrm{H}_{2} \mathrm{O}_{2}$ in Tris buffer within $10 \mathrm{~min}$ at room temperature. Sections were counter stained with Mayer's Hematoxylin for 10 seconds, mounted in DPX and examined under light microscope to analyze the results and to make pictures. Control slides were prepared using the same method omitting either primary or secondary antibodies.

\section{RESULTS}

Immunohistochemical staining of bovine tongue and soft palate showed a great diversity in tissue distribution of the tested proteins. The results were summarized in the Table $2 \& 3$.

\section{A. Tongue:}

Epithelium lining: The stratum granulosum of the stratified squamous keratinized epithelium was immunopositive with desmin in the form of cytoplasmic granulation (Fig. 2a) however it was immunonegative with other tested proteins. S-100 protein was strongly expressed in sensory cells of the taste buds and its unmyelinated nerve fibers in the subepithelial tissue (Fig. 1b). 
Subepithelial tissue: Connective tissue core of vallate papilla, subepithelial connective tissue and nerve bundles in submucosa showed positive immunoreactions with S-100 protein (Fig. 1a, c) $\alpha$ actin (Fig. 1e) but strong immunostaining of subepithelial connective tissue was occurred with vimentin (Fig. 2d).

The lingual glands: Serous secreting cells and duct cells were immunopositive for S-100 protein, which was localized in the nucleus and cytoplasm (Fig.1d) while the supranuclear portion of these cells gave a granular positive reaction for desmin (Fig. 2b). Myoepithelial cells were positively reacted with $\alpha$-actin (Fig. 1f) and desmin (Fig. 2b insert).

Muscles: Smooth muscle fibers of the blood vessels and intrinsic skeletal muscle showed strong reaction for $\alpha$-actin (Fig. 1f) and desmin (Fig. 2c).

Connective tissue core: Vimentin was particularly localized in the connective tissue cells in the inter-glandular and intermuscular connective tissue (Fig. 2e); as well as intralobular connective tissue between the serous acini (Fig. 2f)

\section{B. Soft palate:}

Epithelium lining: The stratum granulosum of the stratified squamous keratinized epithelium was weakly immunoreactive with desmin (Fig. 4a) and negative with other tested proteins. 
Subepithelial and submucosa: The connective tissue cells were strongly immunopositive with vimentin (Fig.4d), weak with S100 (Fig. 3a-insert) and negative with $\alpha$-actin (Fig. 3d) and desmin (Fig. 4a).

Palatine glands: The serous demilunes of the mixed palatine salivary glands was immunopositive with $\mathrm{S}-100$ protein showing strong cytoplasmic and nuclear staining (Fig. 3a, b); however, mucous secreting cells were constantly negative for all tested proteins. On the other hand, myoepithelial cells were positive with $\alpha$-actin (Fig. 3f) and desmin (Fig. 4c).

Muscles: Smooth muscle fibers of blood vessels as well as skeletal muscles were immunopositive with $\alpha$-actin (Fig. 3e-insert, d) and desmin (Fig. 4b-insert, c-insert).

Nerve bundles: Nerve bundles in between the muscular and glandular tissues were positive for S-100 protein (Fig. 3c) and vimentin (Fig. 4e).

Adventitious connective tissue: Fibroblast and fat cells in adventitious connective tissue and around glandular ducts were strongly immunopositive with vimentin (Fig. 4f). 


\section{LEGENDS}

Figure 1: S-100 was expressed in CT core of vallate papilla (a) taste buds (b) and lingual salivary gland (c, d); $\alpha$-actin was present in subepithelial CT (e) skeletal muscles and myoepithelial cells (f, f-arrow). CT, connective tissue; G, glands; D, duct; EP, epithelium; NB, nerve bundles; SK, skeletal muscle; TS, taste buds, V, vallate papilla. Bars $40 \mu \mathrm{m}$

Figure 2: Desmin was expressed in stratum granulosum of tongue epithelium (a) glandular cells (b) myoepithelial cells (b-insert) and skeletal muscle (c); vimentin was present in subepithelial CT (d) interlobular CT (e) and intralobular CT (f). CT, connective tissue; G, glands; D, duct; EP, epithelium; SK, skeletal muscle. Bars $40 \mu \mathrm{m}$

Figure 3: S-100 was expressed in subepithelial CT, dendritic cell (a-insert) and palatine glands of bovine soft palate (a) serous demilunes (b-arrow) and nerve bundles (c); $\alpha$-actin was present in skeletal muscles (d) smooth muscle of b. vs. (e, e-insert) and myoepithelial cells (f). BV, blood vessel; CT, connective tissue; G, glands; D, duct; EP, epithelium; NB, nerve bundles; SK, skeletal muscle; SM, smooth muscle fibers; TS, taste buds. Bars $40 \mu \mathrm{m}$

Figure 4: Desmin was detected in smooth and skeletal muscle (a, b \& c-insert) and myoepithelial cells (c); vimentin was localized in subepithelial CT (d) fibroblast cells (d-insert) nerve bundles (e) and adipose tissue (f). BV, blood vessel; CT, connective tissue; G, glands; D, duct; EP, epithelium; My, myoepithelial cells; NB, nerve bundles; SK, skeletal muscle; SM, smooth muscle fibers. Bars $40 \mu \mathrm{m}$ 
Immunohistochemical Distribution Of S-100 Protein And ...

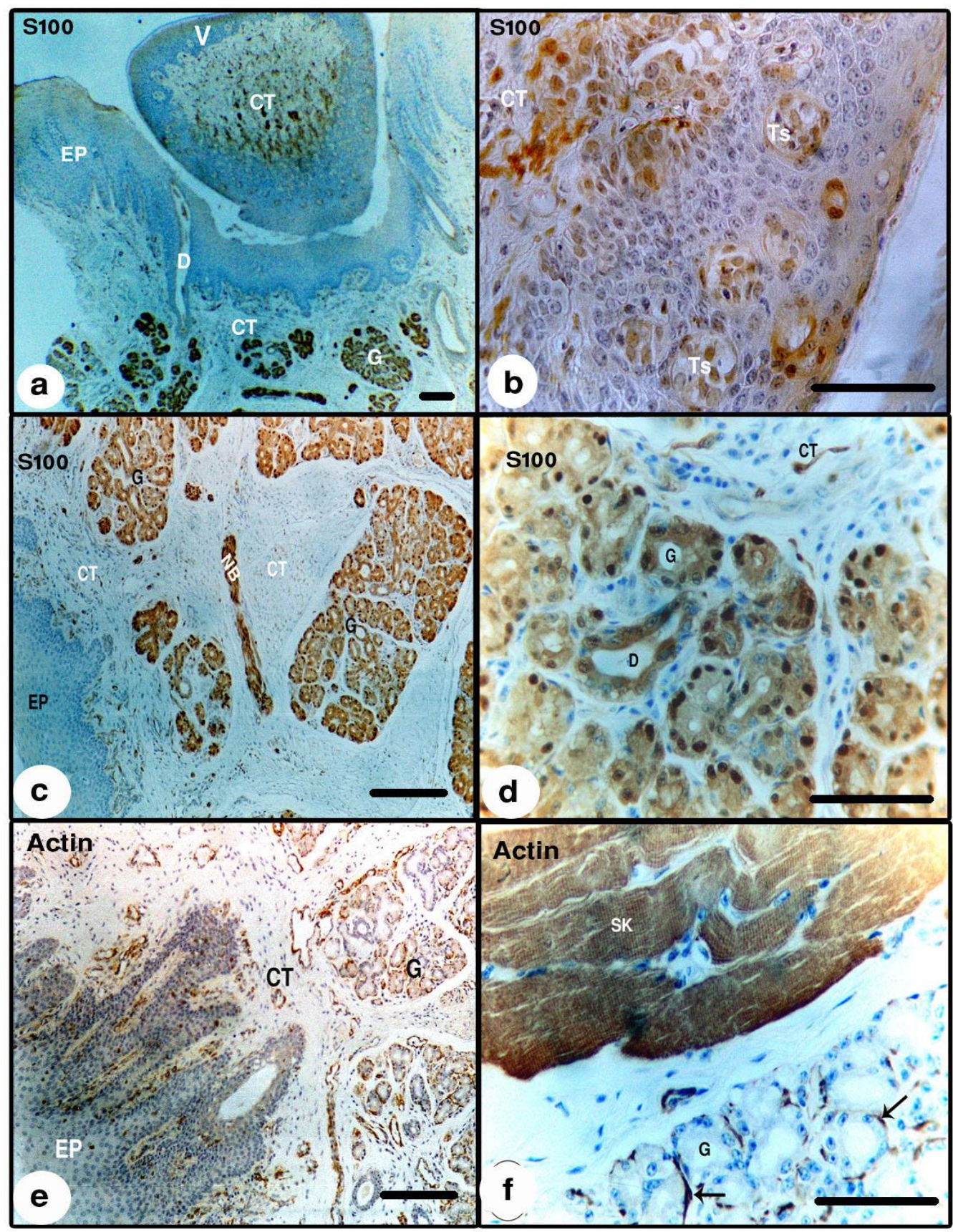

$\overline{\overline{\text { Kafrelsheikh Vet. Med. J. Vol. } 5 \text { No. } 2 \text { (2007) }}}$ 


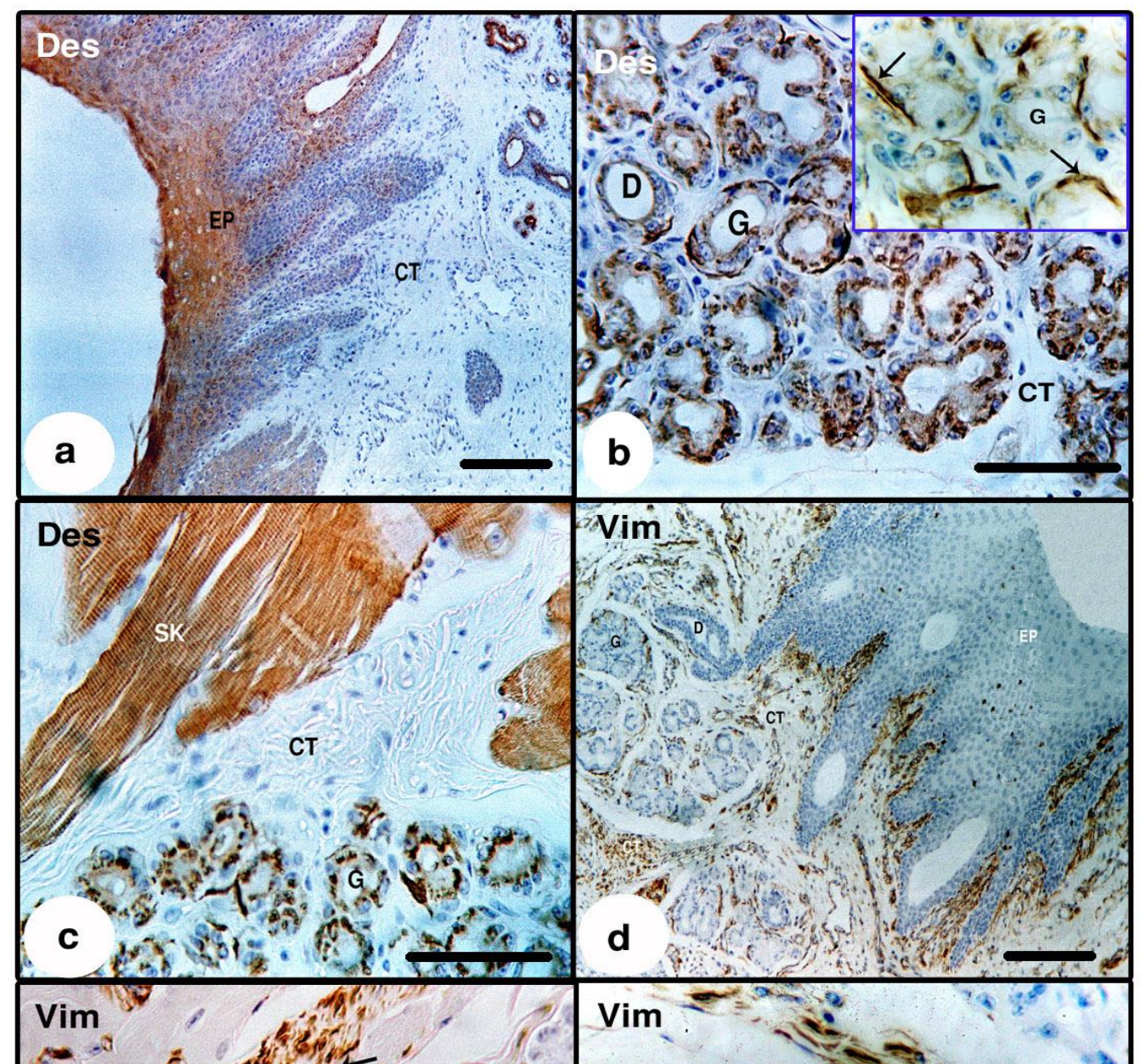




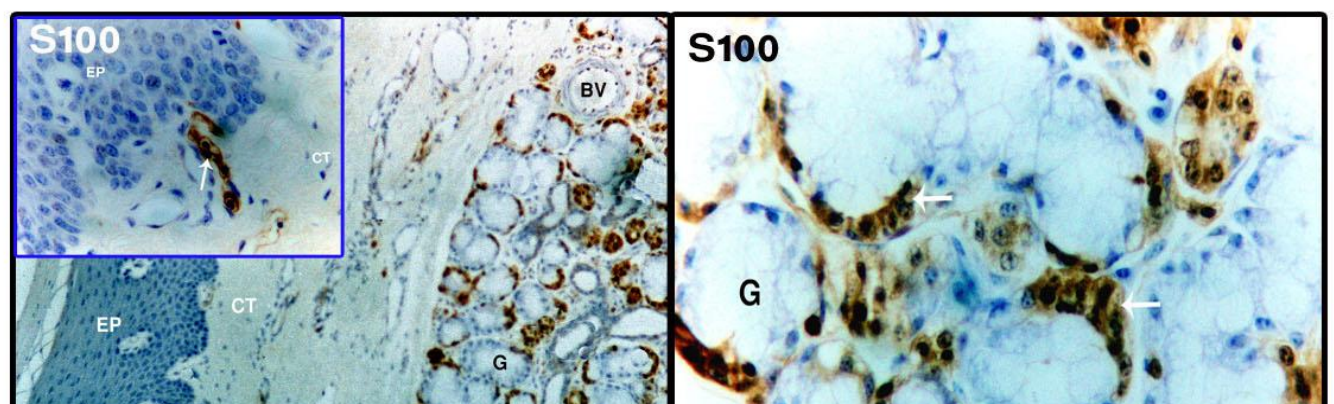




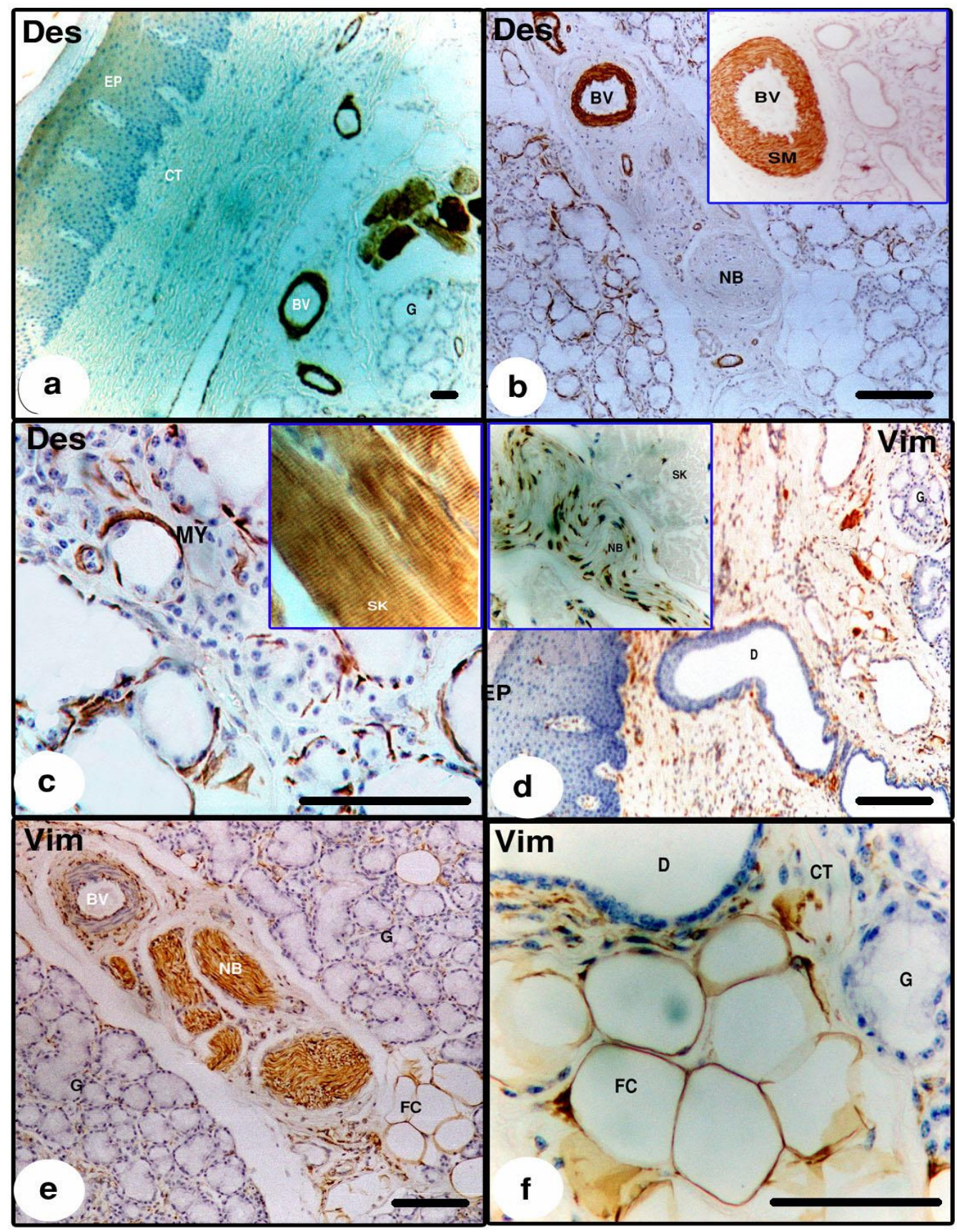


Table (2): Immunoreactivity of S-100 protein and cytoskeleton proteins in bovine tongue $(\mathrm{n}=15)$

\begin{tabular}{|c|c|c|c|c|}
\hline \multirow{2}{*}{ Tongue tissues } & \multirow{2}{*}{$\begin{array}{c}\mathrm{S}-100 \\
\text { protein }\end{array}$} & \multicolumn{3}{|c|}{ Cytoskeleton proteins } \\
\hline & & $\alpha$-actin & Desmin & Vimentin \\
\hline Epithelial & - & - & $+* *$ & - \\
\hline Taste buds & + & - & - & - \\
\hline Subepithelial c. t. and submucosa & + & + & - & $+*$ \\
\hline \multicolumn{5}{|l|}{ palatine glands } \\
\hline - Serous cells & + & - & + & - \\
\hline - Duct cells & + & - & + & - \\
\hline - Myoepithelial cells & - & + & + & - \\
\hline
\end{tabular}




\begin{tabular}{||l||c||c|c|c||}
\hline Nerve bundles & $+*$ & - & - & $+^{*}$ \\
\hline Muscles & - & + & + & - \\
\hline Connective tissue core & - & - & - & $+^{*}$ \\
\hline
\end{tabular}

Table (3): Immunoreactivity of S-100 protein and cytoskeleton proteins in bovine soft palate $(n=15)$

\begin{tabular}{|c|c|c|c|c|}
\hline \multirow{2}{*}{ Soft palate tissues } & \multirow{2}{*}{$\begin{array}{c}\mathrm{S}-100 \\
\text { protein }\end{array}$} & \multicolumn{3}{|c|}{ Cytoskeleton proteins } \\
\hline & & $\alpha$-actin & Desmin & Vimentin \\
\hline Epithelial & - & - & $++^{* * *}$ & 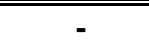 \\
\hline Subepithelial connective tissue & + & - & - & $+*$ \\
\hline palatine glands & & & & \\
\hline - Serous demilunes & $+*$ & - & - & - \\
\hline - Myoepithelial cells & - & + & + & - \\
\hline Nerve bundles & + & - & - & + \\
\hline Muscles & - & + & + & - \\
\hline Adventitious connective tissue & $-/+$ & - & - & $+*$ \\
\hline
\end{tabular}

* Strong reaction

** In stratum granulosum

\section{DISCUSSION}

This immunohistochemical study reveals the presence of S-100 protein in the taste buds and its unmyelinated nerve fibers in the underneath connective tissue in the tongue, as well as nerve bundles in the tongue submucosa and soft palate inter-glandular and inter-muscular tissues. This result was confirming the neurologic origin of S-100 as it was first isolated from the bovine brain tissue and identified in glial and Schwann cells (Turusov, 1990).

In the present study, the serous secreting and duct cells in lingual salivary glands as well as serous demilunes of mixed palatine glands 
were strongly expressed S-100 protein in the form of nuclear and cytoplasmic staining. Similar expression of S-100 was recorded in bovine exocrine glands (Lauboeck and Egerbacher, 1997) and human salivary glands (Nakazato et al, 1985 and Ferraris et al, 2000), in contrary, negative immunoreactivity was found in parotid salivary glands (Dardick et al, 1991; Makino et al, 1992 and Lee et al, 1993). On the other hand, myoepithelial cells showed negative staining with S-100 protein in lingual and palatine salivary glands. These finding were compatible with the results found in myoepithelial cells in bovine nasolabial glands (Zedda and Farina, 1998) and human palatine glands (Dardick et al, 1991). The immunohistochemical studies of S-100 protein gave conflicting results with the myoepithelial cells of salivary glands, it was recorded as being positively stained as reported by (Kahn et al, 1983; Hara et al, 1983; Loeffel et al, 1985; Nakazato et al, 1985; Vanstapel et al, 1986 and Ferraris et al, 2000) and negative in other investigation (Mori et al, 1987; Ninomiya et al, 1989 and Zedda \& Farina, 1998). These variations in the staining patterns were contributed to the use of polyclonal or monoclonal antibodies to S-100 protein or its various subunits (Molin et al, 1984; Takahashi et al, 1984; Vanstapel et al, 1986 and Ninomiya et al, 1989). Because of this variation of S-100 protein expression in the salivary glands myoepithelial cells, the muscletype $\alpha$-actin was considered the more specific markers for myoepithelial cells (Gown et al, 1985; Tsukada et al, 1987 and Guglitta et al, 1988). The data represented here showed the myoepithelial cells of lingual and palatine salivary glands were clearly immunopositive for antisera of $\alpha$ actin and desmin; which indicated the contractile function of myoepithelial cells (Ogawa, 2003). Smooth muscles of blood vessels as well as skeletal muscle fibers were expressing the microfilament $\alpha$-actin and the intermediate filaments desmin confirming their ability to 
contracts (O'Rahilly and Meller, 1994). Vascular smooth muscle cells were distinguished by the predominance of muscle-specific alpha type actin; whereas gamma-type smooth muscle actin was present only as a minor component that reflected a differentiation from the other smooth muscle cells (Gabbiani et al, 1981). Connective tissue cells, principally fibroblasts, around ducts of salivary glands and adipose tissue were strongly expressing vimentin; these findings were compatible with results obtained in palatine tonsils (Koshi et al, 2001). Vimentin was expressed in many cells of mesodermal origin (Azumi and Battifora, 1987). Unlike the other tested proteins, desmin was expressed in the stratum granulosum of the keratinized epithelium in tongue and soft palate; these findings need further studies to be clarified.

In conclusion, our results indicates that $S-100$ protein seems to be a multifunctional protein because it is expressed in migratory dendritic cells and secretory glandular cells beside its specific pattern of distribution; together with the cytoskeletal proteins $\alpha$-actin, desmin and vimentin in tongue and soft palate could be used as biomarkers in bovine salivary glands, muscular and connective tissues.

\section{REFERENCES}

- Amselgruber M, Siowatz, F, Schams D and Lehmann M (1992): S100 protein immunoreactivity in bovine testis. Andrologia, 24: 231235.

- Azumi N and Battifora H. (1987): The distribution of vimentin and keratin in epithelial and non-epithelial neoplasms. A comprehensive immunohistochemical study on formalin- and alcohol-fixed tumors. Am J of Clin Pathol, 88: 286-296. 
- Azumi M., Ben-Ezra J, and Battifora H. (1988): Immunophenotypic diagnosis of leiomyosarcoma and rhabdomyosarcomas with monoclonal antibodies to muscle specific action and desmin in formaline-fixed tissue. Mod Phathol, 1: 469-474.

- Bock $\boldsymbol{E}$ (1978): Nervous system specific proteins. J Neurochem, 30: 7-14.

- Cruzana M, Budipitojo T, De Ocampo G, Sasaki M, Kitamura N and Yamada J (2003): Immunohistochemical distribution of S-100 protein and subunits (S100- $\alpha$ and S100- $\beta$ ) in the swamp-type waster buffalo (Bubalus bubalis) testis. Andrologia, 35: 142-145.

- Dardick I, Stratis M, Parks W, DeNardi F, and Kahn H (1991): S100 protein antibodies do not label normal salivary gland myoepithelium. Histogenetic implications for salivary gland tumors. Am J Pathol, 138 (3): 619-628.

- Fano G, Biocca S, Fulle S, Mariggio M, Belia S and Callisan P (1995): The S-100: a protein family in search of a function. Prog Neurolobiol, 46: 71-82.

- Ferraris M, Carranza M, Arriaga A (2000): A structural and immunocytochemical study of palatine and labial salivary glands from chronic alcoholics. Acta Odontol Latinoam, 13 (2): 113-121.

- Gabbiani G, Schmid E, Winter S, Chaponnier C, De Ckhastonay C, Vandekerckhove J, Werber K and Franke W (1981): Vascular smooth muscle cells differ from other smooth muscle cells: predominance of vimentin filaments and a specific alpha-type actin. Proc Natl Acad Sci USA, 78 (1): 298-302. 
- Gown A, Vogel A, Gorson D and Lu P (1985): A smooth musclespecific monoclonal antibody recognizes smooth muscle actin isozymes. J Cell Biol, 100 (3): 807-813.

- Gugliotta P, Sapino A, Macrí L, Skalli O, Gabbiani G, Bussolati G (1988): Specific demonstration of myoepithelial cells by anti-alpha smooth muscle actin antibody. J Histochem Cytochem, 36 (6): 659663.

- Haimoto H, Hosoda and Kato K (1987): Differential distribution of immunoreactive S100-beta proteins in normal non nervous human tissues. Lab Invest, 57 (5): 489-498.

- Hara K, Ito M, Takeuchi J, Iijima S, Endo T, Hidaka H (1983): Distribution of S-100b protein in normal salivary glands and salivary gland tumors. Virchows Arch A Pathol Anat Histopathol, 401 (2): 237-249.

- Hsu S, Raine L and Fanger H (1981): Use of Avidin-Biotinperoxidase Complex $(\mathrm{ABC})$ in immunoperoxidase techniques: A comparison between $\mathrm{ABC}$ and unlabeled antibody (PAP) procedures. J Histochem Cytochem, 29(4): 577-580.

- Isobe T, Ishioka N, Kocha T and Okuyama T (1982): Chemical structure and molecular evolution of S-100 proteins. In: Protides of the biological fluids. Peeters M (Ed.). Pergamon Press, Oxford, pp. 21-24.

- Lauboeck S and Egerbacher M (1997): Distribution of S-100 protein and its subunits in bovine exocrine glands. Hisochem Cell Biol, 108: 83-93. 
- Lee S, Kim E, Chi J, Hashimura K, Mori M (1993): Immunohistochemical detection of S-100, S-100 alpha, S-100 beta proteins, glial fibrillary acidic protein, and neuron specific enolase in the prenatal and adult human salivary glands. Pathol Res Pract, 189(9): 1036-1043.

- Loeffel S, Gillespie G, Mirmiran S, Miller E, Golden P, Askin F and Siegal $\boldsymbol{G}$ (1985): Cellular immunolocalization of S100 protein within fixed tissue sections by monoclonal antibodies. Arch Pathol Lab Med, 109(2):117-122.

- Kahn H, Marks A, Thom H, Baumal R (1983): Role of antibody to S100 protein in diagnostic pathology. Am J Clin Pathol, 79(3): 341347.

- Makino I, Murakami Y, Murakami M, Saito Y, Wada Y, Nishiyama $Y$ (1992): An immunohistological study of normal parotid gland. Nippon Jibiinkoka Gakkai Kaiho, 95(12): 1923-1930.

- Mc Nutt $N$ (1998): The S-100 family of multipurpose calciumbinding protein. J Cutan Pathol, 25: 521-529.

- Molin S, Rosengren L, Haglid K, Baudier J, Hamberger A (1984): Differential localization of "brain-specific" S-100 and its subunits in rat salivary glands. J Histochem Cytochem, 32(8): 805-814.

- Momotani E, Kubo M, Ishikawa Y, Matsubara Y, Nakajima Y and Yoshino T (1993): Immunohistochemical distribution of S-100 alphapositive cells in bovine mycobacterial and non-myocobacterial granulomas. J Comp Pathol, 108(3): 291-301. 
- Mori M, Tsukitani K, Ninomiya T, Okada Y (1987): Various expressions of modified myoepithelial cells in salivary pleomorphic adenoma. Immunohistochemical studies. Pathol Res Pract, 182(5): 632-646.

- Nagasao J, Yoshioka K, Amasaki H and Motoh K (2002): Expression of S-100 protein in the intercalated duct cells of bovine pancreas. Okajimas Folia Anat Jpn, 78(6): 229-233.

- Nakajima T, Watanabe S, Sato Y, Shimosato Y, Motoi M and Lennert K (1982): S-100 protein in Langerhans cells, interdigitating reticulum cells and histocytosis X cells. Gann, 73(3): 429-432.

- Nakazato Y, Ishida Y, Takahashi K, Suzuki K (1985): Immunohistochemical distribution of S-100 protein and glial fibrillary acidic protein in normal and neoplastic salivary glands. Virchows Arch A Pathol Anat Histopathol, 405(3): 299-310.

- Ninomiya T, Naito R, Okada Y, Kobayashi K, Mori M, Tsukitani K (1989): Immunohistochemical localization of the alpha and beta subunits of S-100 protein in pleomorphic adenoma of the salivary glands. Virchows Arch B Cell Pathol Incl Mol Pathol, 57(1): 63-75.

- Ogawa Y (2003): Immnuocytochemistry of myoepithelial cells in the salivary glands. Prog Histochem Cytochem, 38(4): 343-426.

- O'Rahilly $R$ and Mueller $\boldsymbol{F}$ (1994): Human Embryology and Teratology. Wiley-Liss, New York, Chichester, Brisbane, Toronto, Singapore. 
- Rappersberger, K., Binder, M., Zonzits, E., Hornick, U. andWolff, K. (1990): Immunogold staining of intermediate-sized filaments of the vimentin type in human skin: a postembedding immunoelectron microscopic study. J. Invest. Dermatol, 94 (5): 700-705.

- Rowden G, Boudreau S and Higley H (1985): Langerhans cells and extaepidermal dendritic cells. An investigation in laboratory animals and man with immunomorphological methods. Scand J Immunol, 21(5): 471-478.

- Skalli O, Ropraz P, Trzeciak A, Benzonana G, Gillessen D and Gabbiani $G$ (1986): A mmonoclonal antibody against a smooth muscle actin: A new probe for smooth muscle differentiation. $\mathrm{J}$ of Cell Biol, 103: 2787-2796.

- Takahashi S and Nakano Y (1989): Immunohistochemical demonstration of Langerhans cell in cholesteatoma using an antiserum against S-100 protein. Arch Otorhinolanyngol, 246 (1): 48-52.

- Tsukada T, Tippens D, Gordon D, Ross R, Gown AM (1987): HHF35, a muscle-actin-specific monoclonal antibody. I. Immunocytochemical and biochemical characterization. Am J Pathol, 126 (1): $51-60$.

- Turusov V (1990): Protein S-100 in histological diagnosis of tumors. Arkh Pathol. 52(1): 71-78.

- Vanstapel M, Gatter K, de Wolf-Peeters C, Mason D, Desmet V (1986): New sites of human S-100 immunoreactivity detected with monoclonal antibodies. Am J Clin Pathol, 85(2):160-168. 
- Weber K and Osborn M (1982): Cytoskeleton: definition, structure and gene regulation. Pathol Res Pract, 175: 128-145.

- Weber K and Geisler N (1984): Intermediate-filaments from wool alpha keratins to neurofilaments. A structural overview. The transformed Phenotype. Cold-Spring, Harbar Symposium, P. 153

- Zedda $M$ and Farina $V$ (1998): Immunocytochemical identification of different cell types in bovine nasolabial glands with particular emphasis on cytoskeletal protein expression. Anat Histol Embryol, 27(1): 37-44.

- Zimmer D, Cornwall E, Landar A and Song W (1995): The S-100 protein family: histology, function and expression. Brain Res Bull, 37 : 417-429. 